\title{
Paleogeographic position of the Ordovician rocks from the Svoge Unit, Western Balkan - preliminary results
}

\section{Палеогеографска позиция на ордовишките скали от Свогенската тектонска единица, Западен Балкан - предварителни резултати}

\author{
Stoyan Georgiev ${ }^{1}$, Valeri Sachanski ${ }^{1,2}$, Polina Andreeva ${ }^{1}$, Hristo Kiselinov ${ }^{1}$, Eleonora Balkanska ${ }^{3}$, \\ Iskra Lakova ${ }^{1}$, Stoyan Tanatsiev ${ }^{2}$ \\ Стоян Георгиев ${ }^{1}$ Валери Сачански ${ }^{1,2}$, Полина Андреева ${ }^{1}$, Христо Киселинов ${ }^{1}$, \\ Елеонора Балканска ${ }^{3}$, Искра Лакова ${ }^{1}$, Стоян Танациев ${ }^{2}$
}

\author{
${ }^{1}$ Geological Institute, Bulgarian Academy of Sciences, Acad. G. Bonchev Str., B1. 24, 1113 Sofia; E-mails: kantega@abv.bg; \\ v_sachanski@geology.bas.bg; polina_a@geology.bas.bg; hristo_bk@geology.bas.bg; lakova@geology.bas.bg \\ ${ }^{2}$ University of Mining and Geology, Studentski Grad, Prof. Boyan Kamenov Str., 1700 Sofia; \\ E-mails: valeri.sachanski@mgu.bg; stanatsiev@gmail.com; \\ ${ }^{3}$ Sofia University “St Kliment Ohridski”, 15 Tsar Osvoboditel Blvd., 1504 Sofia; E-mail: balkanska@gea.uni-sofia.bg
}

\begin{abstract}
Two sandstone samples from the upper and lower parts of the Ordovician succession of the Svoge Unit were analyzed in order to determine their detrital zircon $\mathrm{U}-\mathrm{Pb}$ age spectra using laser ablation inductively coupled plasma mass spectrometry (LA-ICP-MS). Multi-dimensional scaling statistical technique allowed a reliable objective identification of the potential source areas in North Africa and paleogeographic reconstructions were made. Both samples indicate a close proximity to the Trans-Saharan Belt provenance, which is the most probable source of the detrital component.
\end{abstract}

Keywords: detrital zircon, Ordovician, Trans-Saharan Belt provenance, Svoge Unit, Bulgaria.

\section{Introduction}

Detrital zircon $\mathrm{U}-\mathrm{Pb}$ geochronology has revealed a great potential for deciphering the early histories of terranes that underwent intense Variscan and Alpine reworking (Žák et al., 2021). In the present work, we have analyzed two sandstone samples from the Ordovician succession of the Svoge Unit in order to determine their detrital zircon $\mathrm{U}-\mathrm{Pb}$ age spectra using laser ablation inductively coupled plasma mass spectrometry (LA-ICP-MS).

\section{Geological setting}

In terms of regional tectonic zonation, the study area is a part of a first-rank late Alpine tectonic unit, the Srednogorie Zone, represented by the Svoge Unit (Dabovski, Zagorchev, 2009). The Svoge Unit is the northernmost fragment of the Srednogorie Zone and is thrust to the north over the West Balkan Unit of the Balkan Zone. The pre-Mesozoic basement of the Svoge Unit is a tectonically overprinted Paleozoic, mainly shale, succession that is topped by Upper Devonian to lowermost Carboniferous flysch. This sequence is a part of the Paleozoic Balkan Terrane (Yanev, 2000) and is overlain, with an angular unconformity, by Upper Carboniferous and/or Permian clastics. The pre-Mesozoic basement of the Svoge Unit was greatly influenced by Variscan and Alpine deformations (Yanev, 2000).

The Ordovician succession that crops out in the Svoge Unit consists of five lithostratigraphic units, from the base upwards (Sachanski, 2015): siltstone-argillite metaformation, the Grohoten Formation, the Tseretsel Formation, the Sirman Formation, and the lowermost part of the Saltar Formation (Fig. 1A).

The Grohoten Formation is composed of gray, dark gray and black shales, and gray and light gray quartzites. In general, the lowermost and middle levels are built up of packages of quartzites. The lower boundary of the unit is a lithologic gradation from the light gray, green to beige metashales of the siltstoneargillite metaformation, or is a sharp lithologic contact with the latter at the base of the lowermost continuous 


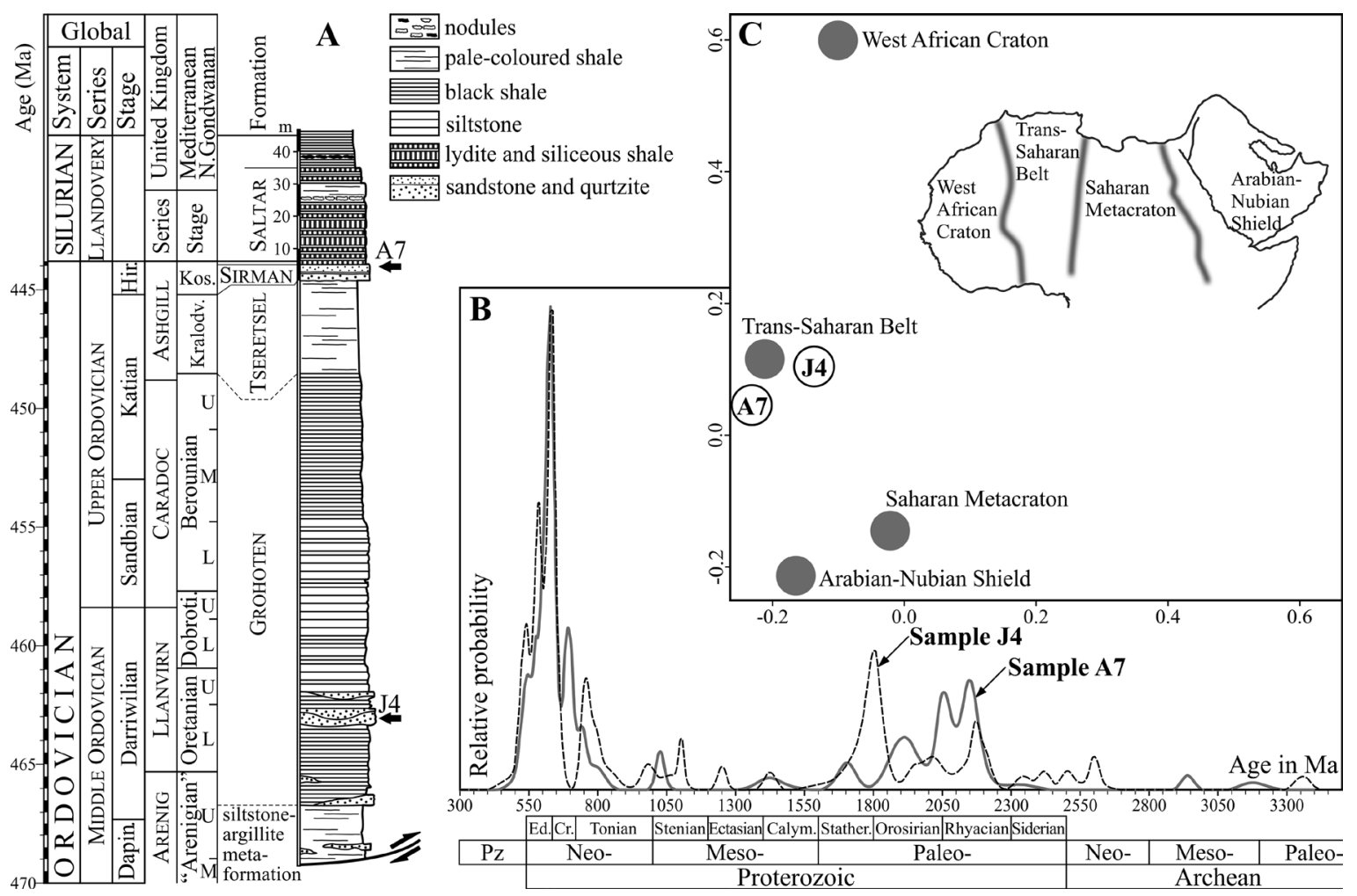

Fig. 1. $A$, lithologic log of the Ordovician in the Svoge Unit with stratigraphic position of the samples A7 and J4; $B$, relative probability plots built up with data from samples A7 and J4; $C$, multi-dimensional scaling plot (MDS) of the analyzed samples compared to potential source areas in Northern Africa (gray). Summarized data of the African detrital provenances from Žák et al. (2021).

quartzite packages. The upper boundary is a short lithologic gradation into the green shales of the Tseretsel Formation. The thickness of the Grohoten Formation is estimated within wide range: $750-800 \mathrm{~m}$ to $3300 \mathrm{~m}$. After revision of all Ordovician finds of trilobites and graptolites (Gutierrez-Marco et al., 2003), the stratigraphical range of the unit was defined to be in the interval Middle-Late Ordovician - Llanvirn and Caradoc series (Oretanian, Dobrotivian, Berounian stages).

The Tseretsel Formation comprises predominantly light gray to grayish-green, indistinctly bedded shales, locally containing siderite concretions. Dark gray centimeter-scale mottles with irregular outlines are also a common feature of this unit. The upper boundary with the sandstones of the Sirman Formation is a sharp lithologic contact. The total thickness varies between 100 $\mathrm{m}$ and $350 \mathrm{~m}$. Despite the absence of fossils, the age of these sediments is assumed to be Ashgill or Kralodvorian on the basis of their stratigraphic position.

The Sirman Formation consists of dark gray to black, thin- to medium-bedded, very fine- to finegrained sandstones alternating with thin beds of dark gray shales. Diamictites are encountered mainly in the lower levels of the section. The upper boundary with the black lydites of the Saltar Formation is a sharp lithologic contact. The total thickness of the unit is about 5-10 m. A detailed sedimentological study of the Hirnantian siliciclastic deposits of the Sirman Formation has been performed by Chatalov (2017), who interpreted a part of them as glaciomarine sediments deposited in an ice-intermediate to ice-distal, lowenergy shelf environment of the intracratonic North Gondwana Platform.

The Ordovician succession ends in the lowermost one-meter thick package of lydites and silicified shales at the base of the Saltar Formation. This unit includes over $30 \mathrm{~m}$ of graptolitic strata ranging in age from lowermost Rhuddanian to early Telychian, except for its first basal one meter, which corresponds to the uppermost Ordovician graptolite zone.

\section{Materials and methods}

We performed detrital zircon analyses on two samples. Sample A7 originates from the upper part of the Sirman Formation, exposed in Saltarski Dol near Batuliya эillage (coordinates WGS84 N 42 $53^{\prime} 22.3^{\prime \prime}$, E $\left.023^{\circ} 26^{\prime} 12.0^{\prime \prime}\right)$. Sample J4 is from the lower half of the Grohoten Formation, cropping out at Grohoten Peak, north of Svoge Town (coordinates WGS84 N $42^{\circ} 58^{\prime} 43.82^{\prime \prime}$, E $\left.23^{\circ} 20^{\prime} 31.60^{\prime \prime}\right)$.

The samples were taken from fresh rocks with weight about $10 \mathrm{~kg}$ each. Zircon grains were separated by standard gravimetric and isodynamic magnetic techniques. After that, the separated zircons were embedded in epoxy resin and polished to expose sections through their centers. Cathodoluminiscence (CL) images were collected prior to zircon analyses to identify inherited cores, cracks and inclusions. U-Pb isotope analyses of particular zircon zones were carried out using a New 
Wave Research (NWR) Excimer 193 nm laser-ablation system attached to a Perkin-Elmer ELAN DRC-e inductively coupled plasma mass spectrometer (LA-ICPMS) at the Geological Institute, Bulgarian Academy of Sciences. The spatial resolution was $35 \mu \mathrm{m}$ and the frequency $-7 \mathrm{~Hz}$. Measurement procedure involved calibration against an external zircon standard GJ-1 $(\sim 604 \pm 3 \mathrm{Ma}$; Jackson et al., 2004) at the beginning, middle part and at the end of the analytical block and crosscheck with secondary zircon standard - Plešovice ( 337.13 $\pm 0.37 \mathrm{Ma}$; Sláma et al., 2008). This technique allows a suitable correction for instrumental drift along with the minimization of elemental fractionation effects. Raw data were processed using Iolite software (Paton et al., 2011). Thus, ${ }^{207} \mathrm{~Pb} /{ }^{206} \mathrm{~Pb},{ }^{208} \mathrm{~Pb} /{ }^{232} \mathrm{Th},{ }^{206} \mathrm{~Pb} /{ }^{238} \mathrm{U}$, and ${ }^{207} \mathrm{~Pb} /{ }^{235} \mathrm{U}$ ratios were calculated and the time-resolved ratios for each analysis were then carefully examined. Optimal signal intervals for the background and ablation data were selected for each sample and automatically matched with the standard zircon analyses. U-Pb Concordia ages were calculated and plotted using ISOPLOT (Ludwig, 2012) and MDS diagrams using IsoplotR (Vermeesch, 2018).

\section{Results}

Sample A7 (Sirman Formation). One hundred spot analyses, predominantly from the rims of the zircon crystals, were performed. The zircons are represented by whole crystals or fragments often with oval shapes due to sedimentary transport, typically $100-250 \mu \mathrm{m}$ in size. They are clear, long to short prismatic. Some of them show well-expressed zonation, while others have unclear oscillatory zonation. The ages form several clusters between: $515-800 \mathrm{Ma}$ (most pronounced), 1026-1030 Ma, 1423-2323 Ma, and 2941-3178 Ma (Fig. 1B).

Sample J4 (Grohoten Formation). Eighty-two spot analyses, predominantly from the rims of the zircon crystals, were performed. The zircons are represented by fragments and whole crystals, often with oval shapes due to sedimentary transport, typically $80-150$ $\mu \mathrm{m}$ in size. They are clear, long to short prismatic. Most of them show unclear oscillatory zonation but well-expressed one can also be observed. Some grains show signs for recrystallization and new overgrowth. The ages form several clusters. The most pronounced peak is between 479-645 Ma. Several peaks between 745-845 Ma, 979-1076 Ma, 1248-2588 Ma, and a single peak of 3350 Ma were also observed (Fig. 1B).

The statistical comparison has been made through multi-dimensional scaling (MDS) to examine the degree of inter-sample similarity and the potential detrital source provenance areas (Fig. 1C).

\section{Conclusions}

Recently, Žák et al. (2021) made an attempt to reveal the detrital provenance of some of the Lower Paleozoic sedimentary rocks from the Balkan region. They showed a "westerly" terrane assemblage, characterized by Mesoproterozoic ages and sourced from the West African Craton and the Trans-Saharan Belt, and an "easterly" assemblage formed next to the Saharan Metacraton and the Arabian-Nubian Shield. Multi-dimensional scaling statistical technique allowed a reliable identification of the potential source areas in North Africa and paleogeographic reconstructions (Fig. 1C). It is visible that both samples from the studied Ordovician sandstones are close to the Trans-Saharan Belt provenance. That allows us to consider that this is the most probable source of the detrital component.

Acknowledgments: This work has been carried out in the framework of the National Science Program "Environmental Protection and Reduction of Risks of Adverse Events and Natural Disasters", approved by the Resolution of the Council of Ministers № 577/17.08.2018 and supported by the Ministry of Education and Science (MES) of Bulgaria (Agreement № Д01-363/17.12.2020).

\section{References}

Chatalov, A. 2017. Sedimentology of Hirnantian glaciomarine deposits in the Balkan Terrane, western Bulgaria: Fixing a piece of the north peri-Gondwana jigsaw puzzle. - Sedim. Geol., 350, 1-22; https://doi.org/10.1016/j.sedgeo.2017.01.004.

Dabovski, H., I. Zagorchev. 2009. Introduction: Mesozoic evolution and Alpine structure. Alpine structure. - In: Zagorchev, I., H. Dabovski, T. Nikolov (Eds.), Geology of Bulgaria, Vol. II, Mesozoic Geology. Sofia, "Prof. M. Drinov" Academic Press, 30-37 (in Bulgarian with English abstract).

Gutierrez-Marco, J. C., S. Yanev, V. Sachanski, I. Rabano, I. Lakova, M. A. San Jose Lancha, E. Diaz Martinez, I. Boncheva, G. Sarmiento. 2003. New biostratigraphical data from the Ordovician of Bulgaria. - INSUGEO, Serie Correlación Geológica, 17, 79-85; http://dgisrv15.unt.edu.ar/fcsnat/insugeo/ geologia 17/11.htm.

Jackson, S. E., N. J. Pearson, W. L. Griffin, E. A. Belousova. 2004. The application of laser ablation-inductively coupled plasma-mass spectrometry to in situ $\mathrm{U} / \mathrm{Pb}$ zircon geochronology - Chem. Geolol., 211, 47-69; http://10.1016/j. chemgeo.2004.06.017.

Ludwig, K. J. 2012. User's manual for Isoplot 3.75. A geochronological toolkit for Microsoft Excell. - In: Berkeley Geochronology Center Special Publication. Berkeley Geochronology Center, CA, 75 p.; http://books.google.com/ books?id=OutNAQAAIAAJ.

Paton, Ch., J. C. Hellstrom, B. Paul, J. Woodhead, J. Hergt. 2011. Iolite: freeware for the visualisation and processing of mass spectrometric data. - J. Anal. At. Spectrom., 26, 2508-2518; https://doi.org/10.1039/C1JA10172B.

Sachanski, V. 2015. The Silurian in the West Balkan Mts. (Svoge Unit, Srednogorie Zone) - 110 years later. - Geologica Balc., $44,1-3,3-15$.

Sláma, J., J. Košler, D. J. Condon, J. L. Crowley, A. Gerdes, J. M. Hanchar, M. S. A. Horstwood, G. A. Morris, L. Nasdala, N. Norberg, U. Schaltegger, B. Schoene, M. N. Tubrett, M. J. Whitehouse. 2008. Plešovice zircon - a new natural reference material for $\mathrm{U}-\mathrm{Pb}$ and $\mathrm{Hf}$ isotopic microanalysis. - Chem. Geol., 249, 1-35; https://doi.org/10.1016/j.chemgeo.2007.11.005.

Vermeesch, P. 2018. IsoplotR: a free and open toolbox for geochronology. - Geoscience Frontiers, 9, 1479-1493; https://doi. org/10.1016/j.gsf.2018.04.001.

Yanev, S. 2000. Palaeozoic terranes of the Balkan Peninsula in the framework of Pangea assembly. - Palaeogeogr., Palaeoclimat., Palaeoecol., 161, 1-2, 151-177; https://doi.org/10.1016/ S0031-0182(00)00121-8.

Žák, J., M. Svojtka, I. Gerdjikov, A. Kounov, D. Vangelov. 2021. The Balkan terranes: a missing link between the eastern and western segments of the Avalonian-Cadomian orogenic belt? - Intern. Geol. Rev., 1-27; https://doi.org/10.1080/00206814. 2020.1861486 